\title{
Relationships among growth and different NOR phenotypes in a specific stock of rainbow trout (Oncorhynchus mykiss)
}

\author{
Porto-Foresti, F. ${ }^{\mathrm{a} *}$, Oliveira, C. ${ }^{\mathrm{b}}$, Tabata, YA. ${ }^{\mathrm{c}}$, Rigolino, $M{ }^{\mathrm{c}}{ }^{\mathrm{c}}$ and Foresti, ${ }^{\mathrm{b}}{ }^{\mathrm{b}}$

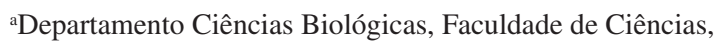 \\ Universidade Estadual Paulista - UNESP, Campus de Bauru, CEP 17033-360, Bauru, SP, Brazil

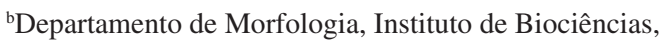 \\ Universidade Estadual Paulista - UNESP, Campus de Botucatu, CEP 18618-000, Botucatu, SP, Brazil \\ 'Agência Paulista de Tecnologia dos Agronegócios, Regional Vale do Paraíba, \\ Estação Experimental de Salmonicultura, Campos do Jordão, SP, Brazil \\ *e-mail: fpforesti@fc.unesp.br
}

Received May 16, 2005 - Accepted September 16, 2005 - Distributed May 31, 2007

(With 3 figures)

\begin{abstract}
Growth is one of the most important aspects in the genetic improvement of cultured fish species. Consequently, genetic parameters related to this feature and their response to selection have been the focus of most research in this area. Such research indicates that, in general, there is enough additive genetic variance related to growth, justifying the use of selection. Based on the usefulness of cytogenetic and molecular markers in the fish culture, the aim of the present work was to analyze the possible relationships among cytogenetic characteristics, specifically the NOR phenotypes, and the increase in length and weight in specimens of the rainbow trout (Oncorhynchus mykiss), resultant from directed mating between homozygous females and heterozygous males according to their NOR phenotypic patterns. The equations of the relationship between length and weight of the analyzed specimens followed the model $\mathrm{Wt}=\mathrm{a} \mathrm{Lt} t^{\mathrm{b}}$, showing $\mathrm{b}$ values higher than 3, determinant of a positive allometric growth. The results showed that the different NOR phenotypes were not related with the growth values for length and weight in any statistical test.
\end{abstract}

Keywords: aquaculture, Oncorhynchus mykiss, chromosome, nucleolar organizer regions (NORs).

\section{Relação entre os diferentes padrões fenotípicos da NOR e crescimento em truta arco-íris (Oncorhynchus mykiss)}

\begin{abstract}
Resumo
O crescimento é um dos mais importantes aspectos considerados no melhoramento genético de espécies de peixes cultivadas. Consequientemente, a ênfase das pesquisas na área tem sido avaliar os parâmetros genéticos relacionados com esta característica e sua resposta à seleção. Essas pesquisas indicam, em geral, haver variância genética aditiva suficiente para justificar o uso da seleção. Considerando que a utilização de marcadores citogenéticos ou moleculares pode ser de grande valia para a piscicultura, o presente trabalho teve como objetivo analisar a possível relação entre as características citogenéticas, de modo específico os padrões fenotípicos das NORs e o crescimento em comprimento e em peso dos exemplares de trutas arco-íris (Oncorhynchus mykiss) resultantes de acasalamentos dirigidos entre fêmeas homozigotas e machos heterozigotos, conforme caracterização do padrão fenotípico da NOR. As equações da relação comprimento e peso dos indivíduos analisados seguiram o modelo onde $\mathrm{Wt}=\mathrm{a} \mathrm{Lt}{ }^{\mathrm{b}}$, mostrando valores de $\mathrm{b}$ maiores que 3 , determinante de um crescimento do tipo alométrico positivo. Os resultados mostraram que os padrões fenotípicos da NOR dos indivíduos homozigotos e dos heterozigotos não apresentaram diferenças estatisticamente significativas entre seus valores de crescimento em comprimento ou peso.
\end{abstract}

Palavras-chave: aquicultura, Oncorhynchus mykiss, cromossomos, região organizadora nucleolar (RONs).

\section{Introduction}

The nucleolar organizer regions (NORs) are the chromosome segments where the $18 \mathrm{~S}, 5.8 \mathrm{~S}$ and $28 \mathrm{~S}$ ribosomal genes are found. The transcription of these genes has been detected by staining the chromosomes with silver nitrate (Miller et al., 1976; Howell and Black, 1980). The silver nitrate staining reveals only active
NORs, since it stains a set of acidic proteins related to the process of ribosomal production and not the ribosomal DNA (Miller et al., 1976).

An important aspect observed in the studies of NORs in fishes is that the number and location of NORs can be species specific or even population spe- 
cific for several groups (Venere and Galetti Jr., 1989; Moreira-Filho and Bertollo, 1991; Maistro et al., 1998). This feature has been successfully used for the establishment of relationship hypothesis among some fish groups (Amemiya and Gold, 1988; Martinez et al., 1993). Examples of the variability of the NORs patterns in fishes have been frequently reported, regarding the number (Miyazawa and Galetti Jr., 1994), location (Gold et al., 1990; Feldberg et al., 1992) and size (Foresti et al., 1981; Moreira-Filho et al., 1984; Martínez et al., 1991).

Studies carried out in the rainbow trout (Oncorhynchus mykiss) indicated that the NORs are located at a subterminal position on the short arms of a submetacentric pair of chromosomes (Schmid et al., 1982; Phillips and Ihssen, 1985; Mayr et al., 1986; Ueda and Kobayashi, 1988; Lloyd and Thorgaard, 1988). However, analyses performed on specimens from a reared stock at the Estação Experimental de Salmonicultura (EES) in Campos do Jordão in the state of São Paulo, showed that the nucleolar organizer regions were located at subterminal position on the long arms of a submetacentric chromosomal pair. Moreover, amongst the 19 specimens analyzed, 13 showed two chromosomes of similar size displaying two different NOR phenotypes: one with a single NOR (condition N1) and another with two consecutive NORs (condition N2) stained by silver nitrate (Oliveira et al., 1996).

After the analysis of 88 specimens of rainbow trout from the EES stock of Campos do Jordão, Porto-Foresti et al. (2004) confirmed the location of NORs on the long arms of a submetacentric pair of chromosomes, as described before by Oliveira et al. (1996). In the same work, the preliminary observations of Oliveira et al. (1996) were also confirmed, i.e., the presence of both NOR phenotypes (condition N1 and condition N2). The data also confirmed that the differences in the NOR positions were due to the occurrence of a pericentric inversion on the NOR-bearing chromosomes pair and not to the condensation of the chromosomes. Specimens displaying the phenotype pattern N1N1 and N1N2 (Figure 1) were identified, but individuals with the N2N2 phenotype were not found among the individuals analyzed in that stock, suggesting that the homozygous condition for double NORs might be lethal.
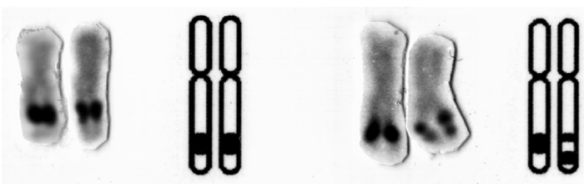

Inv.

Figure 1. Chromosomes of the rainbow trout (Oncorhynchus mykiss) stained with Silver nitrate, showing the nucleolar organizer regions (NOR). a) homozygous condition (N1N1), showing the NOR-bearing chromosome pair with identical interstitial NOR sites on the long arms and b) heterozygous condition (N1N2), showing the NOR-bearing chromosome pair with distinct NOR sites, due to a paracentric inversion.
Growth is one of the most important features considered for genetic improvement purposes of cultured fish species (Gjedrem, 1997; Gjerde, 1986). Consequently, the genetic parameters related to this feature and their response to selection constitute the focus of most research in this area. Such research indicates that, in general, there is enough additive genetic variance related to growth, justifying the use of selection in fishes (Hershberger et al., 1992).

Taking into account that cytogenetical markers can be useful in fish culture, the present work aimed to analyze the possible relationships among cytogenetic characteristics regarding to NOR phenotypic patterns and growth (length and weight) in specimens obtained after managed mating in a rainbow trout stock reared at Campos do Jordão (São Paulo state, Brazil), to provide guidelines for a better zootechnical management of this species.

\section{Materials and Methods}

\subsection{Experimental set}

Six females and six males at reproductive stage were selected from two year-old individuals of rainbow trout broodstock reared at Campos do Jordão (SP, Brazil). The collection of gametes was performed by abdominal pressure of males and females after anesthesia in benzocaine solution (100 mg.L $\mathrm{L}^{-1}$ ) and the NOR phenotype of these animals was analyzed. The gametes collected from each animal were divided into six fractions and mating was conducted assuring that the parental line would represent crossings involving each male with all the females (6 x 6 squedule), resulting in 36 samples. Only mating between homozygous (N1N1) and heterozygous (N1N2) individuals were considered, in order to obtain an offspring composed of 1:1 homozygous and heterozygous individuals.

Such procedure was repeated twice, and the samples obtained from two homozygous (N1N1) females (female $\mathrm{J}$ and female $\mathrm{N}$ ) were selected, resulting in two offspring sets, identified as A (fertilized with semen of 4 heterozygous males) and B (fertilized by 4 heterozygous males), both maintained at the same culture conditions.

Eight months after fertilization, 60 animals were randomly sampled and identified with magnetic tags and maintained in separate sets for growth analysis. Biometric analysis $(\mathrm{Wt}=$ total weight in grammas and $\mathrm{Lt}=$ total length in $\mathrm{cm}$ ) was carried out in all specimens every three months, during a period of 20 months, to evaluate possible growth difference rates among individuals bearing different NOR phenotypes. The biomass weight was calculated monthly to ensure adequate food supply. The feeding rate varied from 2.5 to $1 \%$ of biomass/day, decreasing according to the increase of animal weight.

\subsection{Cytogenetic analysis}


Chromosome preparations were performed from kidney cells after stimulation for mitotic activity (Lozano et al., 1988), at the end of the biometric studies, using in vitro short treatment with colchicines (Foresti et al., 1993). Fifty-six specimens were analyzed, 40 from set A and 16 of set B. The nucleolar organizer regions (NORs) were identified according to the method described by Howell and Black (1980).

\subsection{Growth analysis}

The Student's t-test was applied to evaluate possible significant growth differences among the animals bearing distinct NOR phenotypes, considering the growth curves for weight and length in relation to age in days, as well as the curves obtained by the relationship between total length (Lt) and total weight (Wt), in heterozygous and homozygous individuals from each set separately and from grouped sets. The empirical values of total growth and total length were plotted onto a dispersion graph, adopting the adjusted mathematic expression, following the model $\mathrm{Wt}=\mathrm{a} \mathrm{Lt}^{\mathrm{b}}$, where $\mathrm{a}$ is the condition feature and $b$ represents growth fish performance. The determination coefficient $\left(\mathrm{R}^{2}\right)$ of data converted to logarithms (ln) (Santos, 1978) was also obtained.

\section{Results and Discussion}

\subsection{Cytogenetical analysis}

The cytogenetical data showed 24 specimens bearing the homozygous NOR phenotype (N1N1) and 32 specimens bearing the heterozygous NOR phenotype (N1N2) (Figure 1). The lack of individuals bearing the homozygous N2N2 NOR phenotype was confirmed, as previously described by Oliveira et al. (1996) and also in the offspring obtained in N1N2XN1N2 crosses (PortoForesti et al., 2004).

\subsection{Growth analysis}

The growth data were based on weight and length values obtained from individuals of eight samplings from the sets A and B, separated according to N1N1 and N1N2 NOR phenotypes, as shown in Tables 1 and 2.

The Student's $t$-test applied to analyze the length (Lt) and weight $(\mathrm{Wt})$ curves in relation to age in days, as well as the Wt $\mathrm{x}$ Lt curves in individuals from the sets A and $\mathrm{B}$, characterized as homozygous and heterozygous, respectively, did not reveal significant differences between both phenotypes, as showed in Table 3 .

The growth data were analyzed separately for each phenotypic pattern, providing mean and standard-deviation values for length and weight (Table 4). These data were plotted for the establishment of the correlation among NOR phenotypes and values of length and weight from the individuals (Figures $2 \mathrm{a}$ and $2 \mathrm{~b}$ ). The specimens lacking biometric information were discarded in the analysis.

The relationships between total weight and total length for the homozygous and heterozygous individu- als, are represented in Figure 3. The t-test was not performed over a values because the regression constants were found to be similar.

Concerning the equation of the relationship between length and weight $\left(\mathrm{Wt}=\mathrm{aLt} t^{\mathrm{b}}\right)$, b values were 3.2157 in the
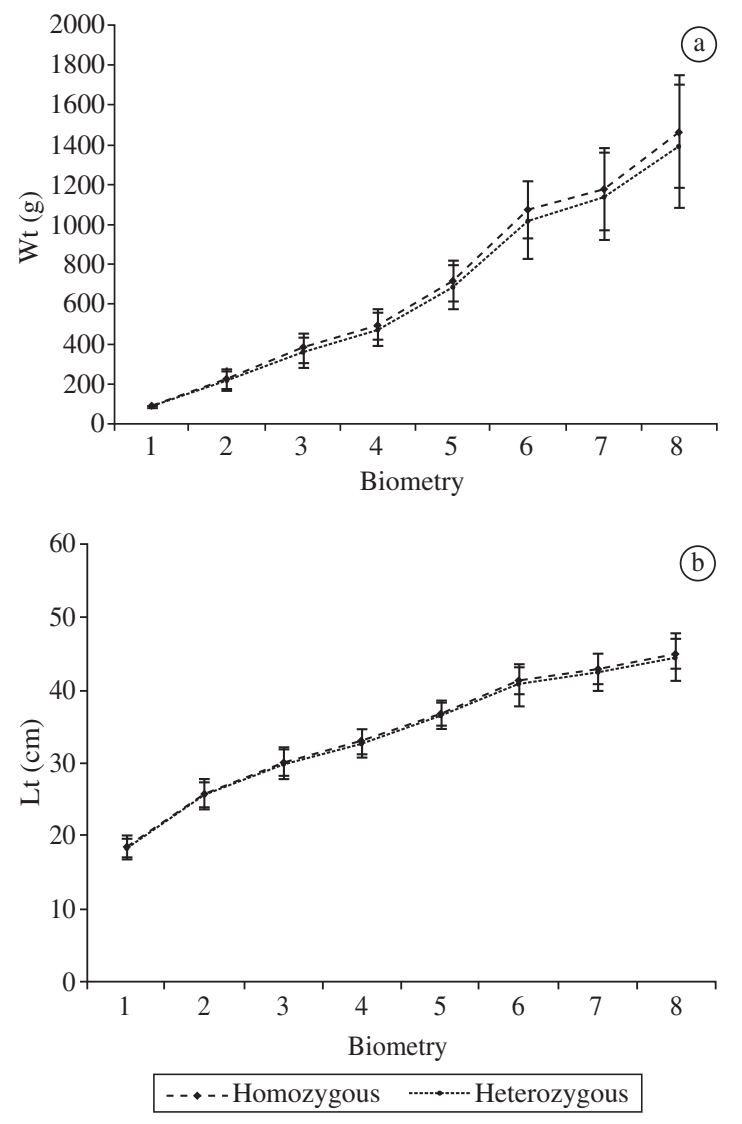

Figure 2. Comparative evaluation of (a) weight gain (g) and (b) size length $(\mathrm{cm})$ means in specimens of rainbow trout (Oncorhynchus mykiss), homozygous (N1N1) and heterozygous (N1N2) for the NOR phenotype.

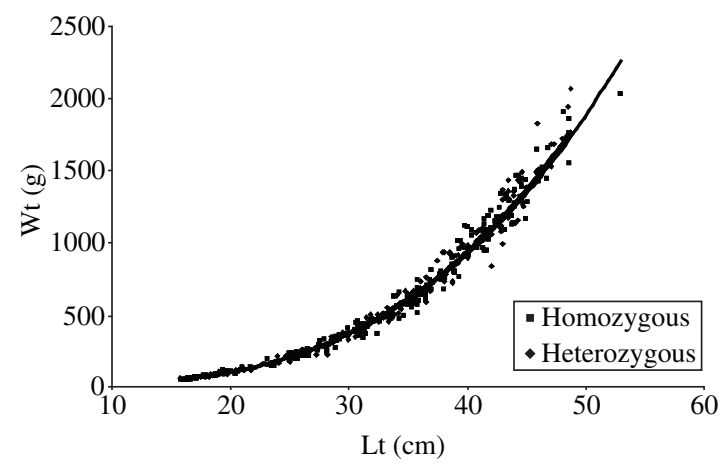

Figure 3. Graphic representation of the relationship between total weight (Wt) and total length (Lt) and the adjusted curve in specimens of rainbow trout (Oncorhynchus mykiss), homozygous (N1N1) and heterozygous (N1N2) for the NOR phenotype. 


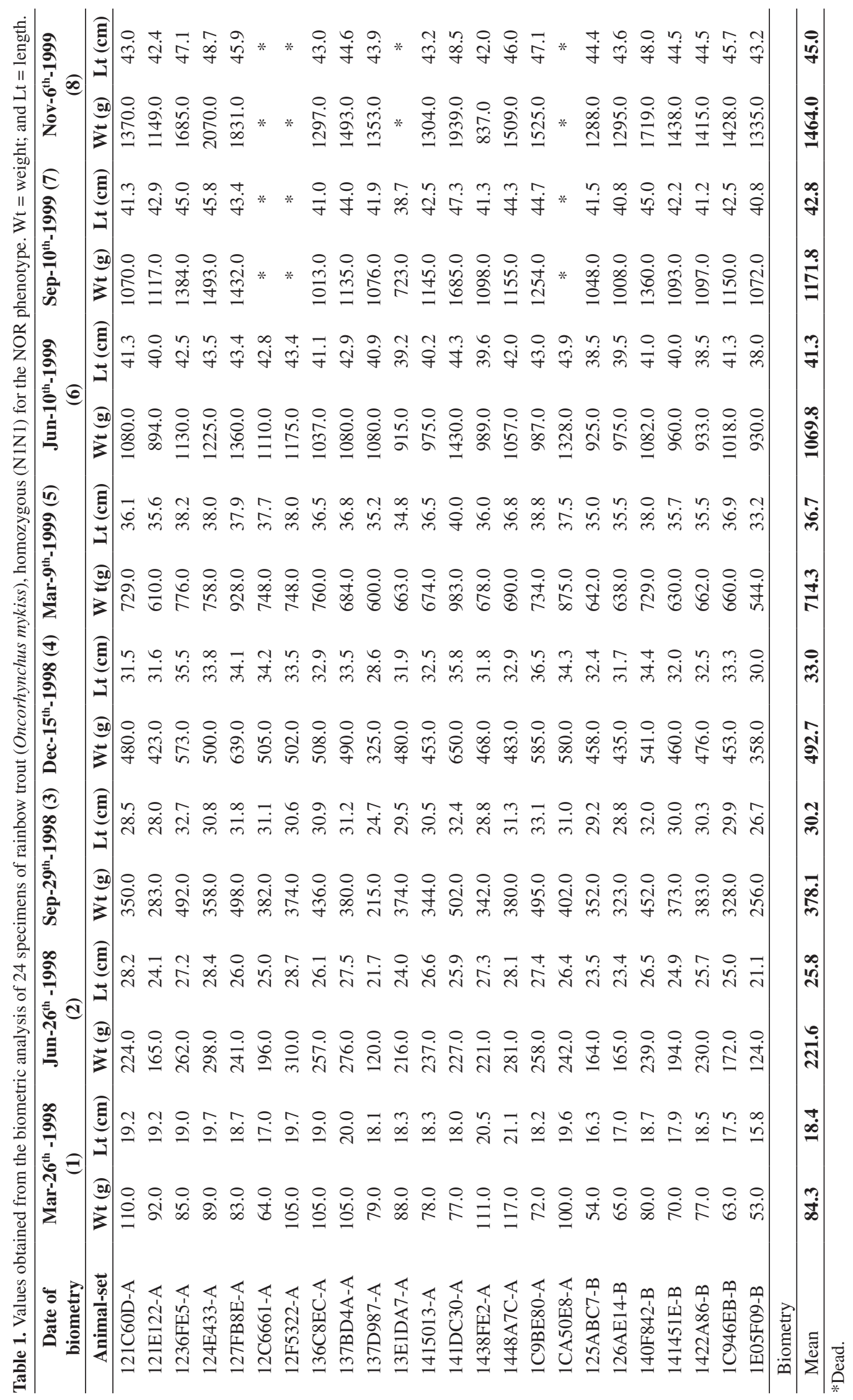




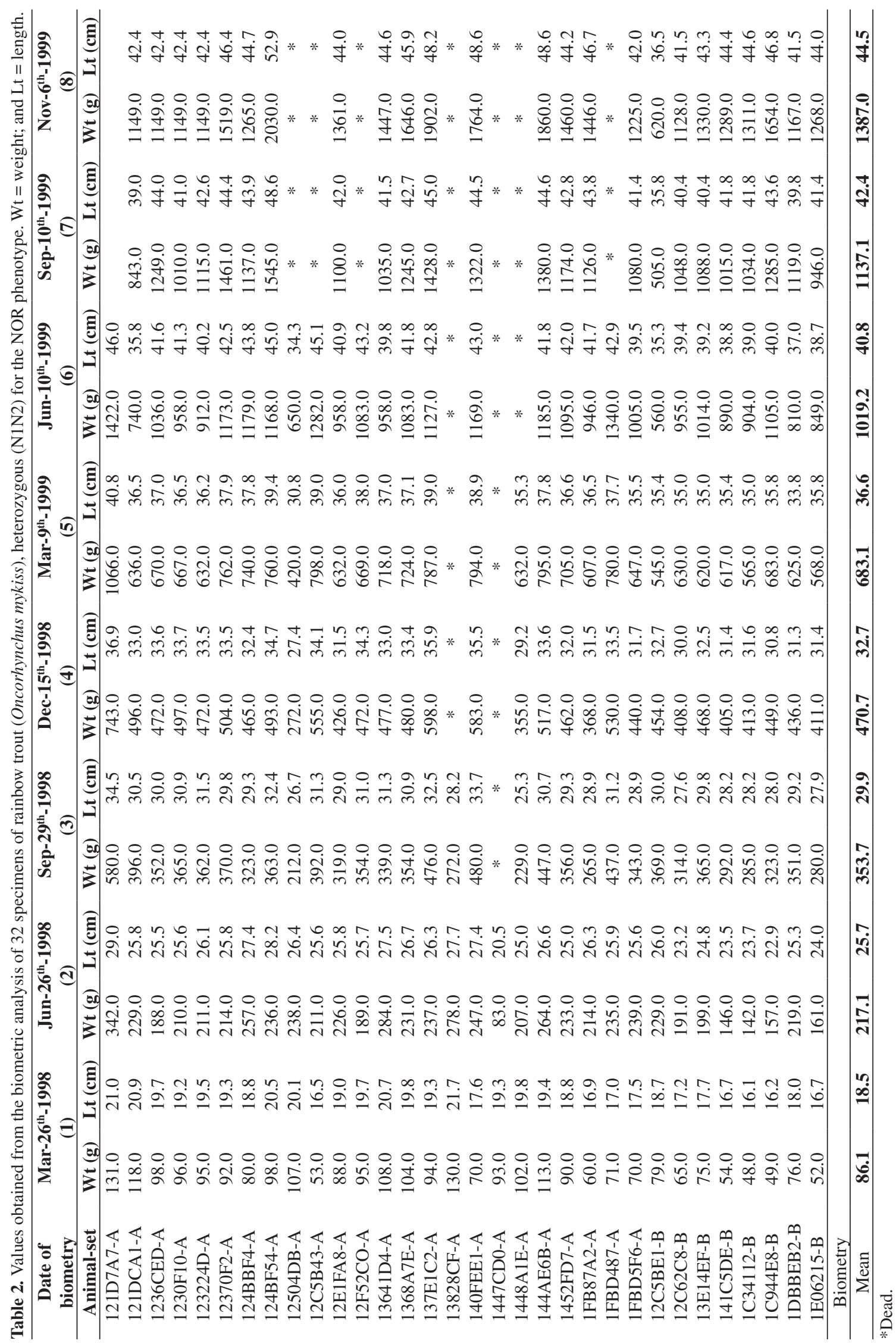


Table 3. $\mathrm{T}$ values obtained from the comparison between specimens of rainbow trout (Oncorhynchus mykiss), heterozygous (N1N2) and homozygous (N1N1) for the Nor phenotype, based on Lt curves (cm) $\mathrm{x}$ age in days, Wt $(\mathrm{g}) \mathrm{x}$ age in days, and $\mathrm{Wt}(\mathrm{g}) \times \mathrm{Lt}(\mathrm{cm}) . \mathrm{Lt}=$ length; $\mathrm{Wt}=$ weight.

\begin{tabular}{|c|c|c|c|c|c|}
\hline & \multirow[b]{3}{*}{ Curves } & \multicolumn{4}{|c|}{ Student's $t$-test } \\
\hline & & \multicolumn{2}{|l|}{ Decline } & \multicolumn{2}{|c|}{ Independent terms } \\
\hline & & $(\mathrm{T}$ critical $=1.96)$ & DF & $(\mathrm{T}$ critical $=2.24)$ & DF \\
\hline \multirow[t]{3}{*}{ Set A } & Lt $x$ age & 0.25663 & 291 & 0.01832 & 292 \\
\hline & Wt $\mathrm{x}$ age & 0.28177 & & 0.96828 & \\
\hline & Lt x Wt & 0.54438 & & 1.05778 & \\
\hline \multirow[t]{3}{*}{ Set B } & Lt $x$ age & 0.37068 & 92 & 1.75028 & 93 \\
\hline & Wt $x$ age & 0.73992 & & 1.25551 & \\
\hline & Lt $x$ Wt & 0.21999 & & 0.08951 & \\
\hline
\end{tabular}

$\mathrm{DF}=$ Degree of freedom

Table 4. Mean, standard deviation, and minimum and maximum values of total length (Lt) and total weight (Wt) of the analyzed specimens of rainbow trout (Oncorhynchus mykiss), heterozygous (N1N2) and homozygous (N1N1) for the Nor phenotype.

\begin{tabular}{|c|c|c|c|c|c|c|}
\hline & \multicolumn{2}{|c|}{ Mean \pm standard deviation } & \multicolumn{2}{|c|}{ Minimum } & \multicolumn{2}{|c|}{ Maximum } \\
\hline & Lt $(\mathbf{c m})$ & Wt $(g)$ & Lt (cm) & Wt (g) & Lt (cm) & Wt $(g)$ \\
\hline Homozygous & $33.7 \pm 8.6$ & $675.3 \pm 472.1$ & 15.8 & 53.0 & 48.7 & 2070.0 \\
\hline Heterozygous & $36.1 \pm 8.6$ & $752.2 \pm 454.1$ & 16.1 & 48.0 & 52.9 & 2030.0 \\
\hline
\end{tabular}

homozygous and 3.212 in the heterozygous specimens. Thus these values are in agreement with the statement that $\mathrm{b}$ values should range from 2.0 to 4.0 ; and, if close to 3.0 , they could be considered isometric (Weatherley and Gill, 1987; King 1995). Furthermore, these values revealed that the specimens presented a positive allometric growth, since $b$ value was higher than 3 , indicating that the weight was increased at a rate higher than that necessary to keep a constant body proportion.

The condition factor was similar in both analyzed sets, suggesting that individual identification by magnetic tags worked as an efficient marking tool in this species, allowing to stock different lines of individuals in the same tank, represented by different NOR phenotypes, and eliminating possible differences due to environment or management processes.

Our growth data based on weight and length values showed some apparent relationship with N1N1 or N2N2 NOR phenotypes. It can be stated that the absence of N2N2 NOR phenotype in this specific stock of rainbow trout, probably due to a lethal effect of the double inverted NOR (Porto-Foresti et al., 2004), is the only situation already described about possible effects of the inversion. Besides, the occurrence of the inversion in a heterozygous condition seems to have no effect in the viability or in the development of individuals. A small deviation favoring the heterozygous condition observed in crosses involving N1N2 x N1N2 NOR phenotypes (Porto-Foresti et al., 2004) is still to be investigated.

Since the characteristics related to growth constitute an important feature for the genetic improvement of cultured aquatic species (Gjedrem, 1997; Gjerde, 1986), the present results demonstrate that the occurrence of a paracentric inversion involving a NOR-bearing chromosomal segment, with the consequent origin of distinct NOR phenotypes, does not seem to present any interference in the growth performance of rainbow trout. The only effect caused by this rearrangement would be the inviability of individuals bearing the $\mathrm{N} 2 \mathrm{~N} 2$ phenotype, as previously demonstrated by Porto-Foresti et al. (2004).

Acknowledgments - The authors are grateful to R. Devidé and AL. Alves for technical assistance, to PM. Galetti Jr., O. Moreira Filho, N. Castagnoli, JF. Lui, for critical review of the original manuscript. F. Porto-Foresti was supported by a fellowship from the Fundação de Amparo à Pesquisa do Estado de São Paulo (FAPESP).

\section{References}

AMEMIYA, CT. and GOLD, JR., 1988. Chromosomal NORs as taxonomic and systematic characters in North American cyprinid fishes. Genetica, vol. 76, p. 81-90.

FELDBERG, E., PORTO, JIR. and BERTOLLO, LAC., 1992. Karyotype evolution in Curimatidae (Teleostei, Characiformes) for the Amazon region. I. Studies on the genera Curimata, Psectrogaster, Steindachnerina and Curimatella. Brazil. J. Genet., vol. 15, no. 2, p. 369-383.

FORESTI, F., ALMEIDA-TOLEDO, LF. and TOLEDOFILHO, SA., 1981. Polymorphic nature of nucleous organizer regions in fishes. Cytogenet. Cell Genet., vol. 31, p. $137-144$.

FORESTI, F., OLIVEIRA, C. and ALMEIDA-TOLEDO, LF., 1993. A method for chromosome preparations from large specimens of fishes using in vitro short treatment with colchicine. Experientia, vol. 49, p. 810-813.

GJERDE, B., 1986. Growth and reproduction in fish and shellfish. Aquaculture, vol. 57, p. 37-55. 
GJEDREM, T., 1997. Selective breeding to improve aquaculture production. World Aquaculture, vol. 28, p. 33-45.

GOLD, JR., LI, YC., SHIPLEY, NS. and POWERS, PK., 1990. Improved methods for working with fish chromosomes with a review of metaphase chromosome banding. J. Fish Biol., vol. 37 , p. 563-575.

HERSHBERGER, WK., 1992. Genetic variability in rainbow trout populations. Aquaculture, vol. 100, p. 51-71.

HOWELL, WM. and BLACK, DA., 1980. Controlled silverstaining of nucleolus organizer regions with a protective colloidal developer: a 1-step method. Experientia, vol. 36, p. 10141015 .

KING, M., 1995. Fisheries biology, assessment and management. Oxford: Fishing News Books, p. 341.

LLOYD, MA. and THORGAARD, GH., 1988. Restriction endonuclease banding of rainbow trout chromosomes. Chromosoma, vol. 96, p. 171-177.

LOZANO, R., REJON, CR. and REJON, MR., 1988. A method for increasing the number of mitoses available for cytogenetic analysis in rainbow trout. Stain Technology, vol. 63, no. 6, p. 335-338.

MAISTRO, EL., OLIVEIRA, C. and FORESTI, F., 1998. Comparative cytogenetic and morfological analysis of Astyanax scabripinnis paranae (Pisces, Characidae, Tetragonopterinae). Genet. Mol. Biol., vol. 21, no. 2, p. 201-206.

MAYR, B., RAB, P. and KALAT, M., 1986. Localisation of NORs and counterstain-enhanced fluorescence studies in Salmo gairdneri and Salmo trutta (Pisces, Salmonidae). Theor. Appl. Genet., vol. 71, p. 703-707.

MARTÍNEZ, P., VINÃS, A., BOUSA, C., ARIAS, J., AMARO, R. and SANCHEZ, L., 1991. Cytogenetical characterization of hatchery stocks and natural populations of Sea and Brown Trout from northwestern Spain. Heredity, vol. 66, p. 9-17.

MARTÍNEZ, P., VINÃS, A., BOUZA, C., CASTRO, J. and SANCHEZ, L., 1993. Quantitative analysis of the variability of nucleolar organizer regions in Salmo trutta. Genome, vol. 36, p. 1119-1123.

MILLER, DA., DEV, VG., TANTRAVAHI, R. and MILLER, OJ., 1976. Supression of human nucleolus organizer activity in mouse-human somatic hybrid cells. Expl. Cell Res., vol. 101, p. 235-243.
MIYAZAWA, CS. and GALETTI JR., PM., 1994. First cytogenetical studies in Characidium species (Pisces: Characiformes, Characidiinae). Cytologia, vol. 59, p. 73-79.

MOREIRA-FILHO, O., BERTOLLO, LAC. and GALLETI JR., P.M., 1984. Structure and variability of nucleolar organizer region in Parondotidae fish. Can. J. Genet. Cytol., vol. 26, no. 5 , p. 564-568.

MOREIRA-FILHO, O. and BERTOLLO, LAC., 1991. Astyanax scabripinnis (Pisces, Characidae): a species complex. Brazil. J. Genet., vol. 14, no. 2, p. 331-357.

OLIVEIRA, C., FORESTI, F., RIGOLINO, MG. and TABATA, YA., 1996. Paracentric inversion involving a NOR-bearing chromosome of rainbow trout (Oncorhynchus mykiss): electron microscopy studies of the synaptonemal complex. Caryologia, vol. 49 , p. 335-342.

PHILLIPS, R. and IHSSEN, PE., 1985. Chromosome banding in salmonid fish: nucleolar organizer regions in Salmo and Salvelinus. Can. J. Genet. Cytol., vol. 27, p. $433-440$.

PORTO-FORESTI, F., OLIVEIRA C., GOMES EA., TABATA YA., RIGOLINO MG. and FORESTI F., 2004. Investigation of a lethal effect associated with a polymorphism involving the NOR-bearing chromosomes in rainbow trout (Oncorhynchus mykiss). Genet. Mol. Biol., vol. 27, no. 1, p. 51-54.

SANTOS, EP. Dinâmica de populações aplicada à pesca e piscicultura. São Paulo: HUCITEC, Ed. da Universidade de São Paulo, 1978, p. 129.

SCHMID, M., LOSER, C., SCHMIDTKE, J. and ENGEL, W., 1982. Evolutionary conservation of a common pattern of activity of nucleolous organizer during spermatogenesis in vertebrates. Chromosoma, vol. 86, p. 149-179.

UEDA, T. and KOBAYASHI, J., 1988. Disappearance of AgNORs originated from brown trout in the allotriploid female rainbow trout and male brown trout. Proc. Japan Acad., vol. 63 b, p. $51-55$.

VÊNERE, PC. and GALETTI JR., 1989. Chromosome evolution andphylogeneticrelationships of someneotropicalCharaciformes of the family Curimatidae. Braz. J. Genet., vol. 12, no. 1, p. $17-25$.

WEATHERLEY, AH. and GILL, HS., 1987. The biology of fish growth. London: Academic Press, p. 443. 
